\title{
Evaluation of an Electrochemical Method for the Analysis of Enzymatic Inhibition Reactions
}

\author{
Kohei Uematsu ${ }^{\dagger}$ and Hajime Katano \\ Faculty of Biotechnology, Fukui Prefectural University, Eiheiji, Fukui 910-1195, Japan
}

\begin{abstract}
An approximate equation for bioelectrocatalitic current was applied to an inhibition reaction analysis of bilirubin oxidase by anion $\left(\mathrm{Cl}^{-}, \mathrm{SCN}^{-}\right.$, and $\left.\mathrm{F}^{-}\right)$in order to assess the possibility of the electrochemical method for the analysis of enzymatic inhibition reactions. The approximate equation can be transformed into the Michaelis-Menten form, so that the bioelectrocatalitic current can be analyzed by the usual graphical manner, that is, Lineweaver-Burk, Hanes-Woolf, Dixon and Cornish-Bowden plots, if the rate of inhibition reaction is described as a simple Michaelis-Menten form. From the electrochemical assay, it was found that the inhibitor of $\mathrm{Cl}^{-}$and $\mathrm{SCN}^{-}$anions exhibit non-competitive inhibition while that of $\mathrm{F}^{-}$exhibits competitive inhibition, and their inhibition constants were 220, 45, and $22 \mathrm{mM}$, respectively. The results were essentially similar to those obtained from the conventional spectrophotometric assay.
\end{abstract}

(Received August 29, 2012; Accepted November 1, 2012; Published January 10, 2013)

\section{Introduction}

Several oxidoreductase reactions can be connected to the electrode reaction through electron transfer mediators. The process is called mediated bioelectrocatalysis, and the process in an homogeneous system where the enzyme, mediator and substrate are dissolved in a test solution has been utilized for the evaluation of enzyme kinetics. ${ }^{1-4}$ Some advantages of the electrochemical method over the usual spectrophotometrical method have been presented for several cases, such as a capability of evaluating a considerably small value of Michaelis constant etc. ${ }^{1,2,4}$ Kano et al. presented an approximate equation for bioelectrocatalytic current that can be transformed into the Michaelis-Menten form. ${ }^{1,2}$ The approximate equation may provide an electrochemical method for analyzing an inhibition reaction by using conventional graphical methods, that is, Lineweaver-Burk (L-B), Hanes-Woolf (H-W), Dixon (D) and Cornish-Bowden (C-B) plots, if the rate of the inhibition reaction can be described as a simple Michaelis-Menten form.

Electrochemical evaluations of inhibition reactions have been widely conducted using an immobilized enzyme electrode for the application of the electrode as a biosensor for detecting and quantifying toxic materials. ${ }^{5}$ The enzyme immobilized electrode is very useful because it can be used repeatedly and allows for a reduction in the required amount of enzyme. However, the immobilization of the enzyme on the electrode surface sometimes changes the properties of the enzyme, such as inhibition type and its constants..$^{5-7}$ Therefore, in certain cases, the electrochemical method based on the enzyme immobilized electrode is not suited for the evaluation of the inhibition reaction itself.

In contrast with electrochemical assay using an enzyme immobilized electrode, there has been little reported on

$\dagger$ To whom correspondence should be addressed.

E-mail: kuematsu@fpu.ac.jp electrochemical assay for inhibition reaction under homogeneous conditions, as far as we know. In this study, the approximate equation for the bioelectrocatalytic currents were applied to an inhibition reaction analysis of bilirubin oxidase (BOD) by anions, including $\mathrm{Cl}^{-}, \mathrm{SCN}^{-}$, and $\mathrm{F}^{-}$, and the results were compared with the results obtained from the spectrophotometric assay in order to assess the validity and utility of the electrochemical assay for the inhibition reaction.

Bilirubin oxidase is a multicopper oxidase and reduces oxygen to water conjugated with the oxidation of bilirubin. ${ }^{8,9}$ BOD has proven to be a promising enzyme for use as a cathode catalyst in biofuel cells, ${ }^{10,11}$ and its stability in solutions has been also studied electrochemically. ${ }^{12-14}$ Like other multicopper enzymes, BOD from Trachyderma tsunodae (T.t. BOD) is inhibited by some anions such as $\mathrm{N}_{3}^{-}, \mathrm{SCN}^{-}, \mathrm{F}^{-}, \mathrm{Cl}^{-}$, and $\mathrm{Br}^{-}$ions. The inhibition, i.e., anion binding properties, in T.t. BOD has been investigated in detail by inhibition kinetics of enzyme activity, spectrophotometric, EPR and stopped-flow methods. ${ }^{15}$ The inhibition type of these anions are reported to be non-competitive with respect to bilirubin. Because bilirubin does not exhibit a well-defined redox reaction at the electrode surface, ${ }^{16}$ we chose hexacyanoferrate(II) ion $\left(\left[\mathrm{Fe}(\mathrm{CN})_{6}\right]^{4-}\right)$ as the reductant for the BOD enzymatic reaction instead of bilirubin, ${ }^{13,17}$ allowing for a comparison between the electrochemical and the spectrophotometrical assays.

\section{Experimental}

\section{Reagents}

Bilirubin oxidase (BOD; EC 1.3.3.5) from Myrothecium verrucaria was donated by Amano Enzyme Inc. (2.83 U/mg, Lot No. BOBO551301). The concentration of BOD in stock solution was determined spectrophotometrically using $\varepsilon_{600}=4800 \mathrm{M}^{-1} \mathrm{~cm}^{-1} .^{18} \quad$ Reagent grade potassium hexacyanoferrate(II) trihydrate $\left(\mathrm{K}_{4}\left[\mathrm{Fe}(\mathrm{CN})_{6}\right]\right)$, potassium hexacyanoferrate (III) $\left(\mathrm{K}_{3}\left[\mathrm{Fe}(\mathrm{CN})_{6}\right]\right)$, potassium chloride $(\mathrm{KCl})$, 
sodium thiocyanate $(\mathrm{NaSCN})$ and sodium fluoride $(\mathrm{NaF})$ were obtained from Wako Pure Chemical Industries. All other chemicals were of reagent grade.

\section{Measurements}

The electrochemical and spectrophotometric measurements were carried out in the following mediator and inhibitor concentration ranges: $\left[\mathrm{K}_{3}\left[\mathrm{Fe}(\mathrm{CN})_{6}\right]\right]=20-196 \mu \mathrm{M}$ and $\left[\mathrm{K}_{4}\left[\mathrm{Fe}(\mathrm{CN})_{6}\right]\right]=30-200 \mu \mathrm{M}$, and $[\mathrm{KCl}]=0-400 \mathrm{mM}$, $[\mathrm{NaSCN}]=0-160 \mathrm{mM}$, and $[\mathrm{NaF}]=0-60 \mathrm{mM}$. The concentrations of BOD in the spectroscopic and electrochemical measurements were $0.35 \mathrm{nM}$ and $0.35-0.76 \mu \mathrm{M}$, respectively. Although the concentrations of BOD for the two measurements were different, we assumed that the difference had no effect on the inhibition reaction mechanism of BOD. Throughout the study, the test solution was buffered at $\mathrm{pH} 7.0$ with $50 \mathrm{mM}$ $\mathrm{NaH}_{2} \mathrm{PO}_{4}-\mathrm{Na}_{2} \mathrm{HPO}_{4}$, and its ionic strength was adjusted to 0.5 with $\mathrm{KNO}_{3}$. The solution was saturated with $\mathrm{O}_{2}$ and its temperature was kept at $25^{\circ} \mathrm{C}$.

The electrochemical measurements, cyclic voltammetry $(\mathrm{CV})$ and amperometry were carried out with a three electrode system. A glassy carbon electrode $(\phi=3 \mathrm{~mm}$ : BAS Co.), a platinum coil and an $\mathrm{AglAgCl}(0.1 \mathrm{M} \mathrm{KCl})$ electrode were used as the working electrode, counter electrode, and reference electrode, respectively. Spectrophotometric measurements were performed with a JASCO V-630 UV VIS spectrophotometer. The enzymatic reaction was followed by a time-dependent increase of the absorbance at $420 \mathrm{~nm}\left(A_{420}\right)$, which corresponds to the absorption maxima of $\left[\mathrm{Fe}(\mathrm{CN})_{6}\right]^{3-}$ ion. ${ }^{13}$ The enzymatic reaction rate, $v$, was determined from the initial slope of the $A_{420}-t$ curve.

\section{Results and Discussion}

Prior to the electrochemical assay, we confirmed from the spectrophotometrical assay whether the inhibition reaction by anion obeys the simple Michaelis-Menten form with respect to the mediator. The equation can be expressed as: ${ }^{19}$

$$
v=\frac{V_{\max , \mathrm{i}}}{K_{\mathrm{M}, \mathrm{i}} /[\mathrm{M}]+1},
$$

where $V_{\mathrm{max}, \mathrm{i}}$ and $K_{\mathrm{M}, \mathrm{i}}$ are the apparent maximum rate and apparent Michaelis constant in the presence of an inhibitor, respectively, and $[\mathrm{M}]$ is the concentration of reductant, i.e. $\left[\mathrm{Fe}(\mathrm{CN})_{6}\right]^{4-}$ (or the concentration of mediator in the electrochemical method). The $V_{\max , \mathrm{i}}$ and $K_{\mathrm{M}, \mathrm{i}}$ may be a function of inhibitor concentration, [i], and the forms of the equations are dependent on the inhibition type. ${ }^{20}$ Figure 1 shows L-B (a), H-W (b), D (c) and C-B (d) plots obtained from the $v$ values through spectrophotometrical measurements at different concentrations of $\left[\mathrm{Fe}(\mathrm{CN})_{6}\right]^{4-}$ and $\mathrm{Cl}^{-}$. All the plots showed good linearity and gave regression lines that intersect at a point on the $\mathrm{x}$-axis. These results indicate that the inhibition type of $\mathrm{Cl}^{-}$is non-competitive with respect to $\left[\mathrm{Fe}(\mathrm{CN})_{6}\right]^{4-}$, and that the $v$ value can be described by Eq. (1). Then, $K_{\mathrm{M}, \mathrm{i}}$ and $V_{\text {max, }}$ are given by: ${ }^{19}$

$$
\begin{aligned}
& K_{\mathrm{M}, \mathrm{i}}=K_{\mathrm{M}} \\
& V_{\max , \mathrm{i}}=V_{\max } /\left(1+[\mathrm{i}] / K_{\mathrm{i}}\right)
\end{aligned}
$$

where, $V_{\max }, K_{\mathrm{M}}$ and $K_{\mathrm{i}}$ are the maximum rate, Michaelis constant of mediator and inhibition constant, respectively. In the non-competitive inhibition, the $\mathrm{x}$-coordinate of the
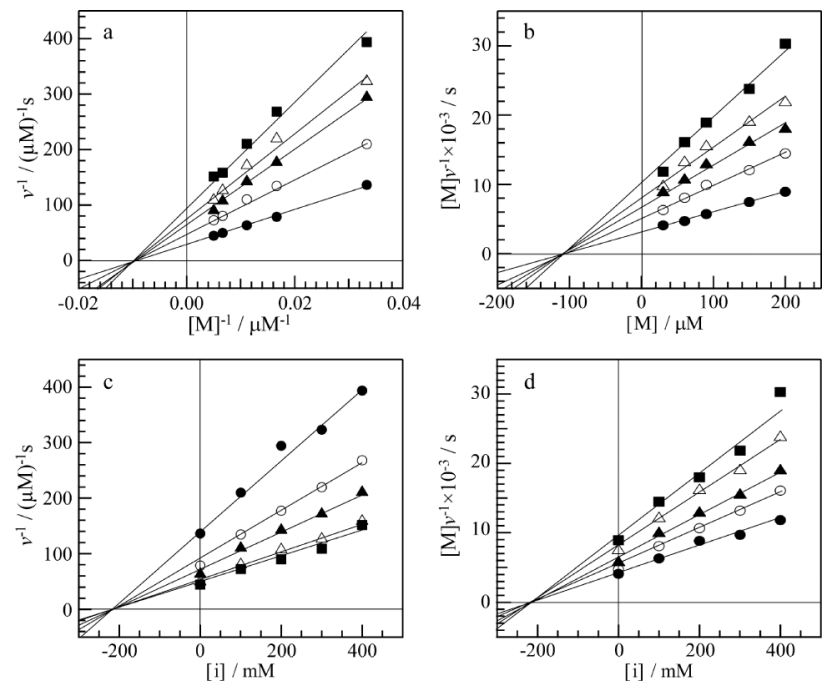

Fig. 1 Dependence of the enzymatic reaction rate $(v)$ on the concentrations of the inhibitor ([i], here $\mathrm{Cl}^{-}$) and the mediator ([M], $\left.\left[\mathrm{Fe}(\mathrm{CN})_{6}\right]^{4-}\right)$ in the form of the (a) L-B and (b) $\mathrm{H}-\mathrm{W}$ plots when [i] $=0$ $(\bullet), 100(\bigcirc), 200(\Delta), 300(\triangle)$ and $400(\mathbf{\square}) \mathrm{mM}$, and the $(\mathrm{c}) \mathrm{D}$ and $(\mathrm{d})$ C-B plots when $[\mathrm{M}]=30(\bullet), 60(\bigcirc), 90(\Delta), 150(\triangle)$ and $200(\mathbf{\square}) \mu \mathrm{M}$ at $[\mathrm{BOD}]=0.35 \mathrm{nM}$.

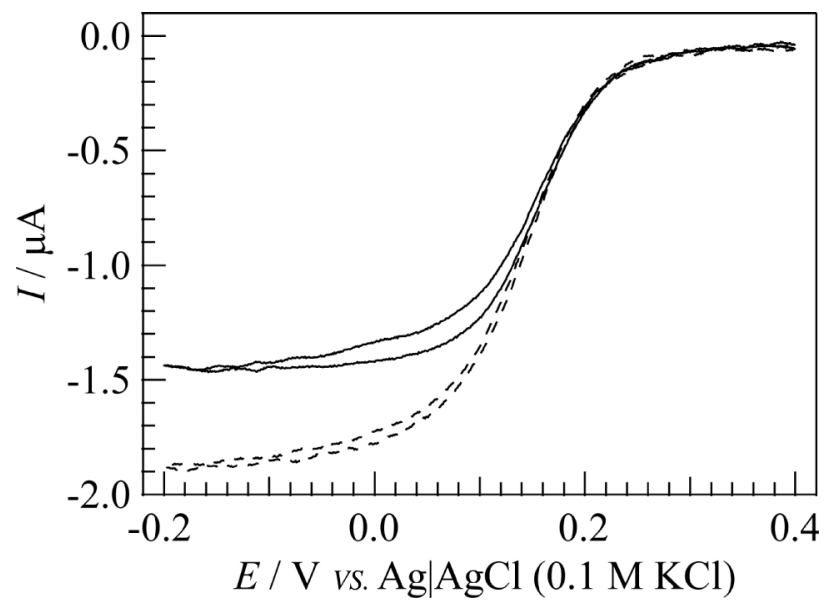

Fig. 2 Cyclic voltammograms (corrected for the base current) recorded in the absence (dashed line) and presence (solid line) of $0.4 \mathrm{M} \mathrm{Cl}^{-}$in a $\mathrm{O}_{2}$-saturated phosphate buffer solution $(\mathrm{pH} 7$, the ionic strength $=0.5$ adjusted with $\mathrm{KNO}_{3}$ ) containing $0.66 \mu \mathrm{M}$ BOD and $50 \mu \mathrm{M} \mathrm{K}_{3}\left[\mathrm{Fe}(\mathrm{CN})_{6}\right]$. Scan rate, $2 \mathrm{mV} \mathrm{s}^{-1}$.

intersection point in the $\mathrm{D}$ and $\mathrm{C}-\mathrm{B}$ plots is equal to $-K_{\mathrm{i}}$, and the $K_{\mathrm{i}}$ value of $\mathrm{Cl}^{-}$was determined to be $220 \mathrm{mM}$ from both plots c and d. The inhibition type and the $K_{\mathrm{i}}$ value of $\mathrm{Cl}^{-}$correspond with those of T.t. BOD. ${ }^{15}$

To determine an appropriate experimental condition for the electrochemical assay, CVs of a test solution containing $\mathrm{K}_{3}\left[\mathrm{Fe}(\mathrm{CN})_{6}\right]$ and BOD in the absence and presence of an inhibitor were recorded. The dashed line in Fig. 2 shows $\mathrm{CV}$ (corrected for the base current) of the $\mathrm{O}_{2}$-saturated test solution (pH 7.0) containing $0.66 \mu \mathrm{M}$ BOD and $50 \mu \mathrm{M} \mathrm{K}_{3}\left[\mathrm{Fe}(\mathrm{CN})_{6}\right]$. The CV exhibited the S-shaped current vs. potential (I-E) curve with a well-defined limiting current $\left(I_{1}\right)$, and the $I_{1}$ substantially decreased when the test solution was deaerated by argon gas (data not shown). The results indicate that a $\left[\mathrm{Fe}(\mathrm{CN})_{6}\right]^{4-13-}$-mediated bioelectrocatalytic reaction conjugated 


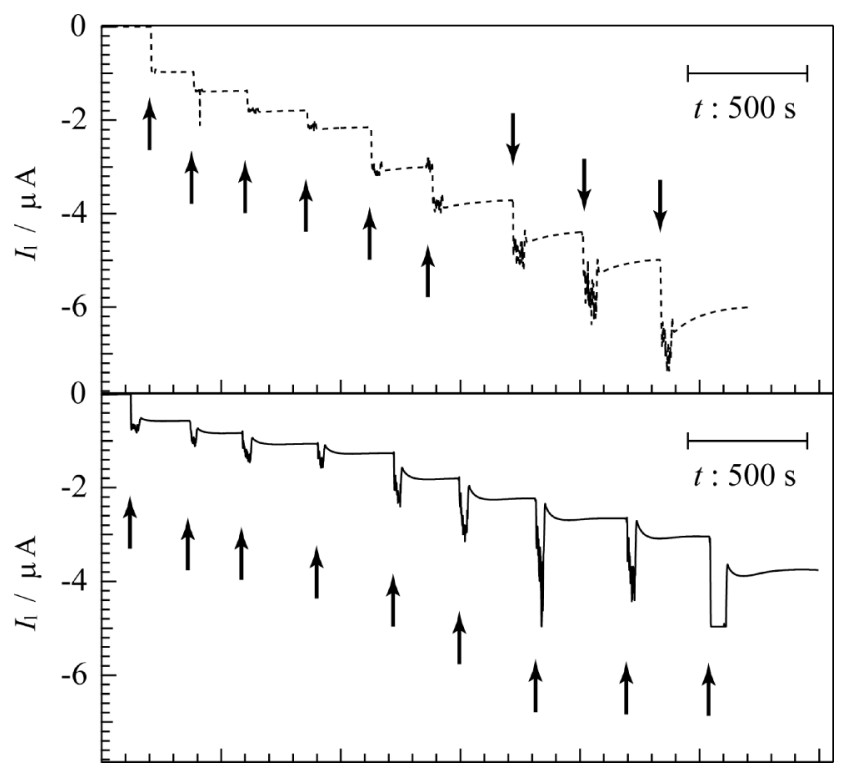

Fig. 3 Amperometric response to the successive addition of the mediator $\left(\mathrm{K}_{3}\left[\mathrm{Fe}(\mathrm{CN})_{6}\right]\right)$ to the test solution containing $0.76 \mu \mathrm{M}$ BOD in the absence (dashed line) and presence (solid line) of $0.4 \mathrm{M} \mathrm{Cl}^{-}$. The concentration of mediator was increased from 0 to $196 \mu \mathrm{M}$ by successive additions (arrows).

with the reduction of $\mathrm{O}_{2}$ by BOD takes place. ${ }^{8}$ When the $\mathrm{Cl}^{-}$ was added to the test solution up to $0.4 \mathrm{M}$, the bioelectrocatalytic reduction current decreased as shown by the solid line in Fig. 2, indicating the inhibition of the BOD enzymatic reaction by $\mathrm{Cl}^{-}$. The half wave potential was essentially unchanged by the addition of $\mathrm{Cl}^{-}$, and $I_{1}$ was obtained below $-0.05 \mathrm{~V}$ in both the absence and presence of $\mathrm{Cl}^{-}$. Thus, the current at a constant potential of $E=-0.10 \mathrm{~V}$ was determined as the $I_{1}$ in the following inhibition assays. Figure 3 shows examples of the amperometric response at $-0.10 \mathrm{~V}$ upon successive additions of the mediator into $\mathrm{O}_{2}$-saturated test solution $(\mathrm{pH} 7.0)$ containing $0.76 \mu \mathrm{M}$ BOD in the absence (dashed line) and presence (solid line) of $0.4 \mathrm{M} \mathrm{KCl}$. The arrows in this figure indicate the addition of the mediator to the test solution with the solution stirred. After the stirring was stopped, a steady-state current was recorded as the $I_{1}$. As seen in the experimental results, in the electrochemical assay, the concentration dependence of the enzymatic activity can be obtained readily by successive addition of the mediator or the inhibitor.

The analytical and approximate equations for $I_{1}$ have been derived as a function of mediator concentration under conditions of $K_{\mathrm{s}} \gg>$ [S], where $K_{\mathrm{s}}$ and [S] are Michaelis constant and concentration of substrate. ${ }^{1-3}$ In that case, $v$ can be expressed as $V_{\max } /\left(K_{\mathrm{M}} /[\mathrm{M}]+1\right)$. Then, the approximate equation for $I_{1}$ can be expressed in the Michaelis-Menten form, as given by: ${ }^{1,2}$

$$
\frac{I_{1}^{2}}{[\mathrm{M}]}=\frac{2\left(n_{\mathrm{M}} F A\right)^{2} D_{\mathrm{M}}\left(n_{\mathrm{S}} / n_{\mathrm{M}}\right) V_{\max }}{2 K_{\mathrm{M}} /[\mathrm{M}]+1}
$$

where $n_{\mathrm{M}}$ and $n_{\mathrm{S}}$ are the number of electron in the electrode reaction and enzymatic redox reaction, respectively, $A$ the surface area of the electrode, $D_{\mathrm{M}}$ the diffusion coefficient of $\mathrm{M}$, and $F$ the Faraday constant. The $V_{\max }$ in Eq. (4) corresponds to $k_{\text {cat }}[\mathrm{E}]$ in Ref. 2. In the presence of an inhibitor, if $v$ is described by the simple Michaelis-Menten form, that is, Eq. (1), the equation of $I_{1}$ also can be described by the same form as Eq. (4) because $V_{\mathrm{max}, \mathrm{i}}$ and $K_{\mathrm{M}, \mathrm{i}}$ are not functions of [M]. Then, the
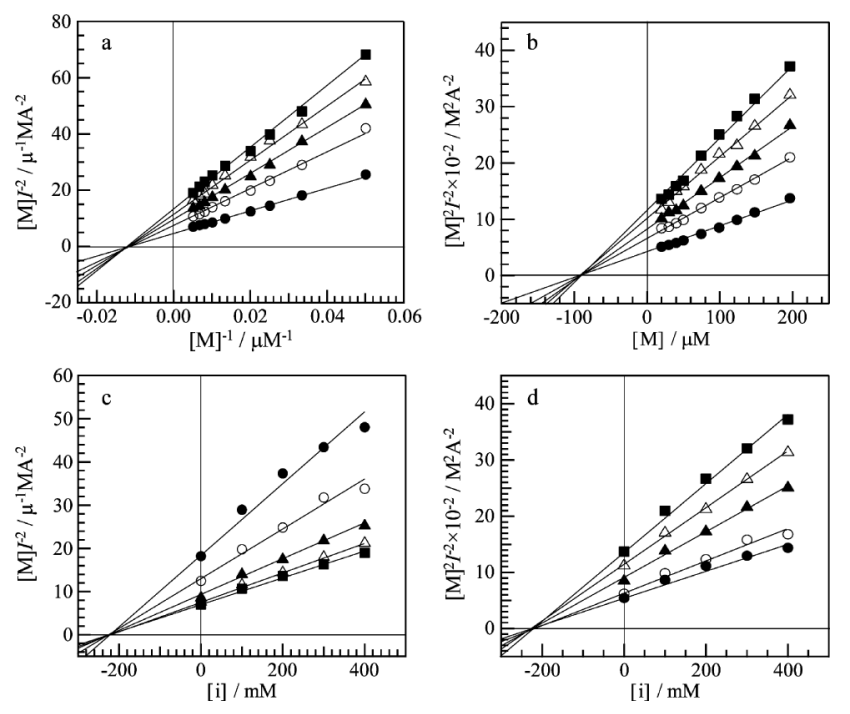

Fig. 4 Dependence of the limiting current $\left(I_{1}\right)$ on the concentrations of $\mathrm{Cl}^{-}([\mathrm{i}])$ and $\left[\mathrm{Fe}(\mathrm{CN})_{6}\right]^{3-}([\mathrm{M}])$ in the form of the (a) $[\mathrm{M}] I_{1}^{-2} v s$. $[\mathrm{M}]^{-1}$ (L-B type) and (b) $[\mathrm{M}]^{2} I_{1}^{-2} v s$. [M] (H-W type) plots when $[\mathrm{i}]=0$ $(\bullet), 100(\bigcirc), 200(\Delta), 300(\triangle)$ and $400(\mathbf{\square}) \mu \mathrm{M}$, and the $(\mathrm{c})[\mathrm{M}] I_{1}^{-2}$ vs. [i] (D type) and (d) [M] $]^{2} I_{1}^{-2}$ vs. [i] (C-B type) plots when [M] = $30(\mathbf{O})$, $50(\bigcirc), 99(\mathbf{\Delta}), 148(\triangle)$ and $196(\boldsymbol{\square}) \mu \mathrm{M}$ at $[\mathrm{BOD}]=0.64 \mu \mathrm{M}$.

equation of $I_{1}$ in the presence of an inhibitor is given by:

$$
\frac{I_{1}^{2}}{[\mathrm{M}]}=\frac{2\left(n_{\mathrm{M}} F A\right)^{2} D_{\mathrm{M}}\left(n_{\mathrm{S}} / n_{\mathrm{M}}\right) V_{\mathrm{max}, \mathrm{i}}}{2 K_{\mathrm{M}, \mathrm{i}} /[\mathrm{M}]+1}
$$

The reciprocal of the Eqs. (4) and (5) indicates that $[\mathrm{M}] I_{1}^{-2}$ and $[\mathrm{M}]^{2} I_{1}^{-2}$ are proportional to $[\mathrm{M}]^{-1}$ and $[\mathrm{M}]$, respectively.

Figures 4(a) and 4(b) show $[\mathrm{M}] I_{1}^{-2} v s .[\mathrm{M}]^{-1}$ and $[\mathrm{M}]^{2} I_{1}^{-2} v s$. [M] plots at different concentrations of $\mathrm{Cl}^{-}$. These plots correspond to the L-B and $\mathrm{H}-\mathrm{W}$ plots, that is, Figs. 1(a) and 1(b). The other type plots, D and C-B plots, are also obtained by the plots of $[\mathrm{M}] I_{1}^{-2} v s$. [i] and of $[\mathrm{M}]^{2} I_{1}{ }^{-2} v s$. [i] at different $[\mathrm{M}] \mathrm{s}$, respectively, as shown by in Figs. 4(c) and 4(d). All plots gave good linearity and gave regression lines that intersect at a point on the $\mathrm{x}$-axis. These results indicate that the inhibition type of $\mathrm{Cl}^{-}$is non-competitive with respect to $\left[\mathrm{Fe}(\mathrm{CN})_{6}\right]^{4-}$ and that the inhibition constant was determined to be $220 \mathrm{mM}$. These results of electrochemical assay agree well with spectrophotometrical assay results.

For $\mathrm{SCN}^{-}$ion, the inhibition type was also deduced to be non-competitive from both the electrochemical and the spectrophotometrical assays. However, the values of $K_{\mathrm{i}}$, which were determined to be 45 and $120 \mathrm{mM}$ from the electrochemical and spectrophotometrical assays, respectively, were somewhat different. One of the possible reasons is a difference in the affinity of the BOD for $\mathrm{SCN}^{-}$according to the redox state of the BOD. It has been reported that some multicopper oxidases exhibit a strong dependency of the affinity of anions on the redox state of the enzyme. ${ }^{21,22}$ In the case of spectrophotometrical assay, the enzymatic reaction occurs in the balk solution, meaning that the BOD is surrounded by substantial $\left[\mathrm{Fe}(\mathrm{CN})_{6}\right]^{4-}$. On the other hand, in the electrochemical assay, the enzymatic reaction takes place in the proximity of the electrode surface, meaning that substantial $\left[\mathrm{Fe}(\mathrm{CN})_{6}\right]^{4-}$ exists only in the vicinity of the electrode surface. The different conditions for the enzymatic reaction may result in different ratios of the oxidized and reduced BOD, leading to different values of $K_{\mathrm{i}}$. 

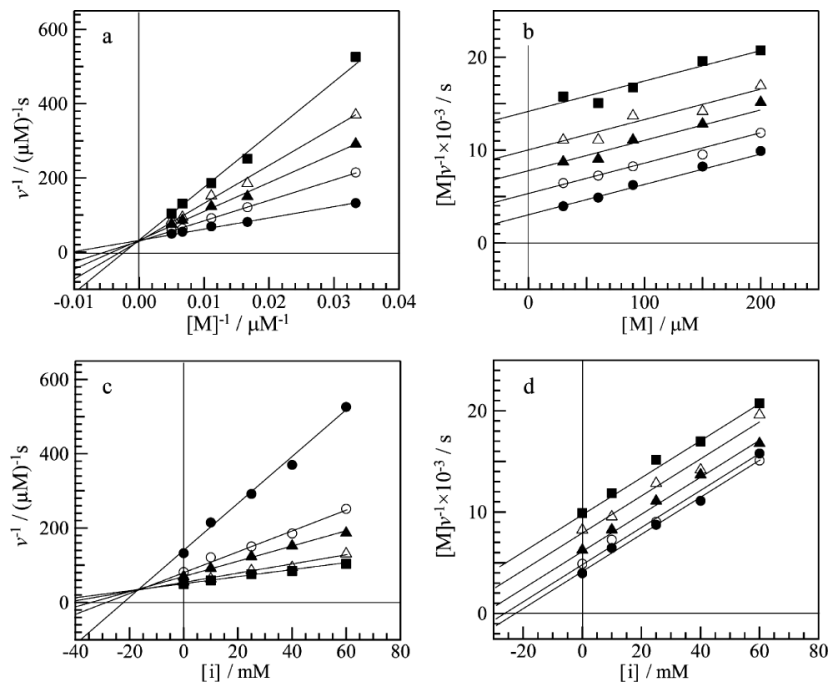

Fig. 5 Dependence of $v$ on the concentrations of $\mathrm{F}^{-}$([i]) and $\left[\mathrm{Fe}(\mathrm{CN})_{6}\right]^{4-}([\mathrm{M}])$ in the form of the (a) L-B and (b) H-W plots when [i] = $0(\bullet), 10(\bigcirc), 25(\bullet), 40(\triangle)$ and $60(\square) \mathrm{mM}$, and the (c) D and (d) C-B plots when $[\mathrm{M}]=30(\bullet), 60(\bigcirc), 90(\Delta), 150(\triangle)$ and $200(\boldsymbol{\square})$ $\mu \mathrm{M}$ at $[\mathrm{BOD}]=0.35 \mathrm{nM}$.

The inhibition type of $\mathrm{SCN}^{-}$for the BOD is consistent with the type for T.t. BOD. ${ }^{15}$ However, the $K_{\mathrm{i}}$ value is considerably larger than that of T.t. BOD $(94 \mu \mathrm{M})$. This implies that the inhibition property of anions against BOD is dependent on the origin of BOD.

For $\mathrm{F}^{-}$ion, the inhibition type was not determined to be non-competitive. Figure 5 shows L-B, H-W, D and C-B plots obtained from the spectrophotometrical assay in the presence of $\mathrm{F}^{-}$. The regression lines in the $\mathrm{L}-\mathrm{B}$ and $\mathrm{D}$ plots intersect at a point on the $\mathrm{y}$-axis and in the second quadrant, and those of $\mathrm{H}-\mathrm{W}$ and $\mathrm{C}-\mathrm{B}$ plots are parallel. The results indicate that the inhibition is competitive. In competitive inhibition, $K_{\mathrm{M}, \mathrm{i}}$ and $V_{\text {max,i }}$ of Eq. (1) can be given as: ${ }^{19}$

$$
\begin{aligned}
& K_{\mathrm{M}, \mathrm{i}}=K_{\mathrm{M}} /\left(1+[\mathrm{i}] / K_{\mathrm{i}}\right) \\
& V_{\mathrm{max}, \mathrm{i}}=V_{\max }
\end{aligned}
$$

Then, the x-coordinate of the intersection point for the regression lines in the $\mathrm{D}$ plot is equal to $-K_{\mathrm{i}}$ and the $K_{\mathrm{i}}$ value of $\mathrm{F}^{-}$was determined to be $17 \mathrm{mM}$. The difference of the inhibition type from other anions $\left(\mathrm{Cl}^{-}\right.$and $\left.\mathrm{SCN}^{-}\right)$might be related to the size of anion. The $K_{\mathrm{i}}$ value is in agreement with the value for T.t. BOD..$^{15}$ However the inhibition type is different from that of T.t. BOD (non-competitive inhibition).

In the electrochemical assay for inhibition by $\mathrm{F}^{-}$, atypical results were obtained. In the lower concentration region of $\mathrm{F}^{-}$ $(<5 \mathrm{mM})$, the catalytic current steeply decreased with the concentration of $\mathrm{F}^{-}$and the decline of $I_{1}$ led to a deviation from a regression line derived from the higher concentration region in the graphical analysis. An example of the deviation is shown in Fig. 6, where $[\mathrm{M}] I_{1}^{-2}$ is plotted against [i] when $[\mathrm{M}]=50 \mu \mathrm{M}$. The $[\mathrm{M}] I_{1}^{-2}$ values below $5 \mathrm{mM}$ of [i] were smaller than those calculated by the linear function. The unexpected behavior also may be connected with the difference in the affinity of the BOD for $\mathrm{F}^{-}$depending on the redox state of the BOD.

Using $I_{1}$ value when $[\mathrm{i}]>10 \mathrm{mM},[\mathrm{M}] I_{1}^{-2} v s .[\mathrm{M}]^{-1},[\mathrm{M}]^{2} I_{1}^{-2} v s$. $[\mathrm{M}]$, and $[\mathrm{M}] I_{1}^{-2}$ vs. [i], and $[\mathrm{M}]^{2} I_{1}^{-2}$ vs. [i] are plotted in Fig. 7. The results indicate also that the inhibition of $\mathrm{F}^{-}$ion is

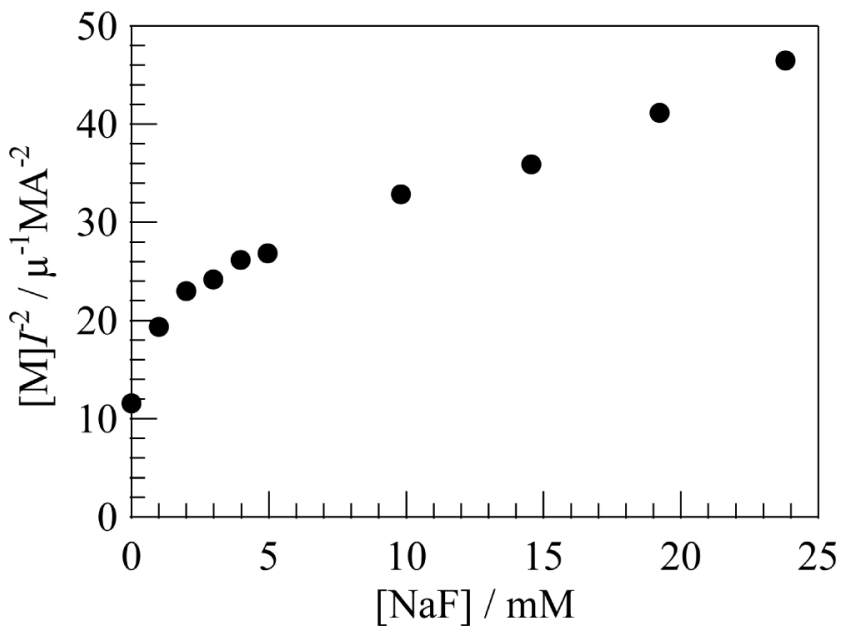

Fig. 6 Dependence of $[\mathrm{M}] I_{1}^{-2}$ on the concentration of $\mathrm{F}^{-}$at $[\mathrm{BOD}]=0.35 \mu \mathrm{M}$ and $[\mathrm{M}]=50 \mu \mathrm{M}$.
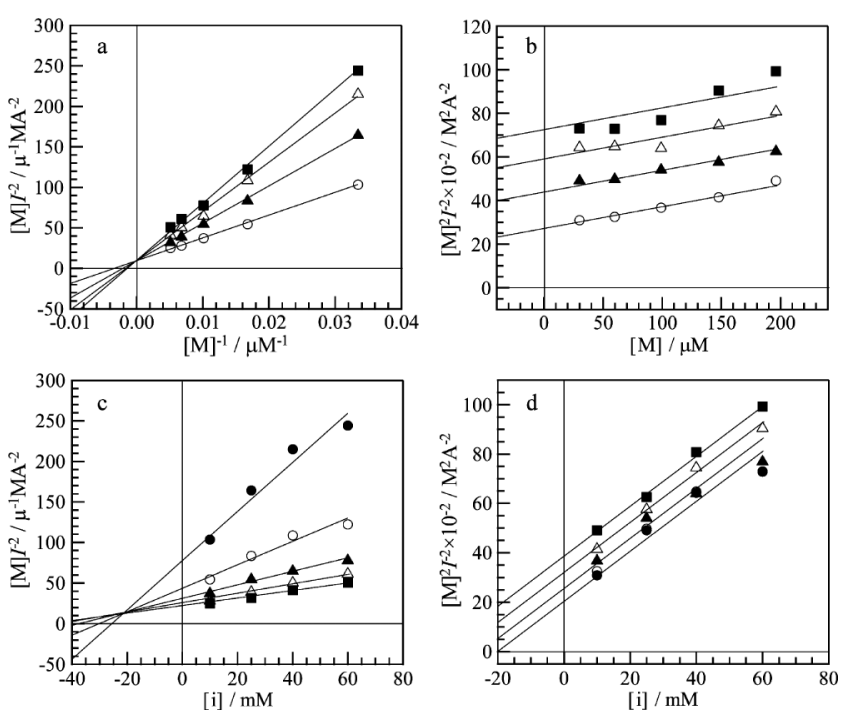

Fig. 7 Dependence of the $I_{1}$ on the concentrations of $\mathrm{F}^{-}$([i]) and $\left[\mathrm{Fe}(\mathrm{CN})_{6}\right]^{3-}([\mathrm{M}])$ in the form of the (a) $[\mathrm{M}] I_{1}^{-2} v s .[\mathrm{M}]^{-1}(\mathrm{~L}-\mathrm{B}$ type $)$ and (b) $[\mathrm{M}]^{2} I_{1}^{-2} v s .[\mathrm{M}](\mathrm{H}-\mathrm{W}$ type) plots when $[\mathrm{i}]=10(\bigcirc), 25(\mathbf{\Delta}), 40(\triangle)$ and $60(\mathbf{\square}) \mathrm{mM}$, and the (c) $[\mathrm{M}] \mathrm{I}_{1}^{-2} v s$. [i] (D type) and (d) $[\mathrm{M}]^{2} I_{1}^{-2} v s$. [i] (C-B type) plots when $[\mathrm{M}]=30(\bullet), 50(\bigcirc), 99(\Delta), 148(\triangle)$ and $196(\square) \mu \mathrm{M}$ at $[\mathrm{BOD}]=0.35 \mu \mathrm{M}$.

competitive. The $K_{\mathrm{i}}$ value was determined to be $22 \mathrm{mM}$ from plot (c), which is in harmony with that obtained by spectrophotometric assay.

Consequently, the above results suggest that the inhibition reaction of BOD can be studied also by the electrochemical method. The electrochemical assay essentially gave similar results to those from spectrophotometric assay. To evaluate the utility of the electrochemical assay for the inhibition reaction, further research using other enzymatic inhibition reactions are required.

\section{Acknowledgements}

The authors thank Prof. T. Ikeda for the useful comments and suggestions. 


\section{References}

1. K. Kano, T. Ohgaru, H. Nakase, and T. Ikeda, Chem. Lett., 1996, 439.

2. T. Ohgaru, H. Tatsumi, K. Kano, and T. Ikeda, J. Electroanal. Chem., 2001, 496, 37.

3. R. Matsumoto, K. Kano, and T. Ikeda, J. Electroanal. Chem., 2002, 535, 37.

4. K. Takagi, K. Yamamoto, K. Kano, and T. Ikeda, Eur. J. Biochem., 2001, 268, 470 .

5. F. Arduini, A. Amine, D. Moscone, and G. Palleschi, Anal. Lett., 2009, 42, 1258

6. M. Stoycheva, Electroanalysis, 2002, 14, 923.

7. I. Narli, S. Kiralp, and L. Toppare, Anal. Chim. Acta, 2006, $572,25$.

8. N. Tanaka and S. Murao, Agric. Biol. Chem., 1982, 46, 2499.

9. N. Tanaka and S. Murao, Agric. Biol. Chem., 1985, 49, 843.

10. S. C. Barton, J. Gallaway, and P. Atanasov, Chem. Rev., 2004, 104, 4867.

11. "Biodenkikagaku no Jissai-Biosensa·Biodenchi no Jitsuyou Tenkai (Practical Bioelectrochemistry-Recent Developments in Biosensors \& Biofuel Cells, in Japanese)", ed. T. Ikeda, 2007, CMC Publishing, Tokyo.

12. T. Ikeda, H. Tatsumi, H. Katano, M. Wanibuchi, T. Hibi, and T. Kajino, Anal. Sci., 2008, 24, 237.
13. H. Katano, H. Tatsumi, T. Hibi, T. Ikeda, and T. Tsukatani, Anal. Sci., 2008, 24, 1421.

14. H. Katano, K. Uematsu, T. Hibi, T. Ikeda, and T. Tsukatani, Anal. Sci., 2009, 25, 1077.

15. J. Hirose, K. Inoue, H. Sakuragi, M. Kikkawa, M. Minakami, T. Morikawa, H. Iwamoto, and K. Hiromi, Inorg. Chim. Acta, 1998, 273, 204.

16. B. Shoham, Y. Migron, A. Riklin, I. Willner, and B. Tartakovsky, Biosens. Bioelectron., 1995, 10, 341.

17. T. Nakagawa, S. Tsujimura, K. Kano, and T. Ikeda, Chem. Lett., 2003, 32, 54.

18. A. Shimizu, T. Sasaki, J. H. Kwon, A. Odaka, T. Satoh, N. Sakurai, T. Sakurai, S. Yamaguchi, and T. Samejima, J. Biochem., 1999, 125, 662.

19. K. Hiromi, "Kousohannou (in Japanese)", 1991, Iwanamishoten, Tokyo.

20. Usual text books, for example, "M. Dixon and E. C. Webb, Enzymes, 3rd ed., 1979, Longman Group Ltd., London”, express Eq. (1) using $K_{\mathrm{M}}, V_{\max }, K_{\mathrm{i}}$ and [i] directly without use of $K_{\mathrm{M}, \mathrm{i}}$ and $V_{\text {max,i }}$ according to the inhibition type, as desribed in Eqs. (2) and (3). However, in this report $K_{\mathrm{M} \text {, }}$ and $V_{\text {max,i }}$ were used to clarify the correspondence relation between Eqs. (4) and (5).

21. D. J. Spira-Solomon, M. D. Allendorf, and E. I. Solomon, J. Am. Chem. Soc., 1986, 108, 5318.

22. L. Casella, M. Gullotti, G. Pallanza, A. Pintar, and A. Marchesini, Biochem. J., 1988, 251, 441. 